\section{STUDENT ADOPTION OF A NON- TRADITIONAL TEACHING METHOD IN ACCOUNTING: HOW PREVIOUS EXPERIENCE IMPEDES WILLINGNESS TO CHANGE}

\begin{abstract}
This research paper examines a new teaching method consisting of a real-life case study that is used in accountancy and its introduction at two universities. The research was conducted at universities that specialise in preparing students to become managers. The main focus of the study is to examine the different ways that students might accept the new teaching method. We consider the utilisation of an active form of teaching, as opposed to a passive form, which is the more prevalent form of teaching accountancy in the Czech Republic. Since the use of active forms of teaching brings a range of advantages, case studies are rarely used, so we were interested to see the students' reaction. The research was conducted over two consecutive academic years and the main factors that were examined to assess the introduction of real-life case studies were country, gender and previous experience with accountancy education at secondary school. The results clearly show that men accept the new way of teaching better than women. Students with previous experience perceived case studies negatively. The results of the study indicate that when introducing changes to teaching, the need to introduce the changes must be appropriately clarified.
\end{abstract}

\section{KEYWORDS}

Accounting education, change acceptance, managerial decision-making, problem-based learning, real-life case studies

\section{HOW TO CITE}

Stejskalová I., Komárková L., Bednářová M., Štrach P. (2019) 'Student Adoption of a Non-Traditional Teaching Method in Accounting: How Previous Experience Impedes Willingness to Change', Journal on Efficiency and Responsibility in Education and Science, vol. 12, no. 1, pp. 01-11. http://dx.doi.org/10.7160/eriesj.2019.120101

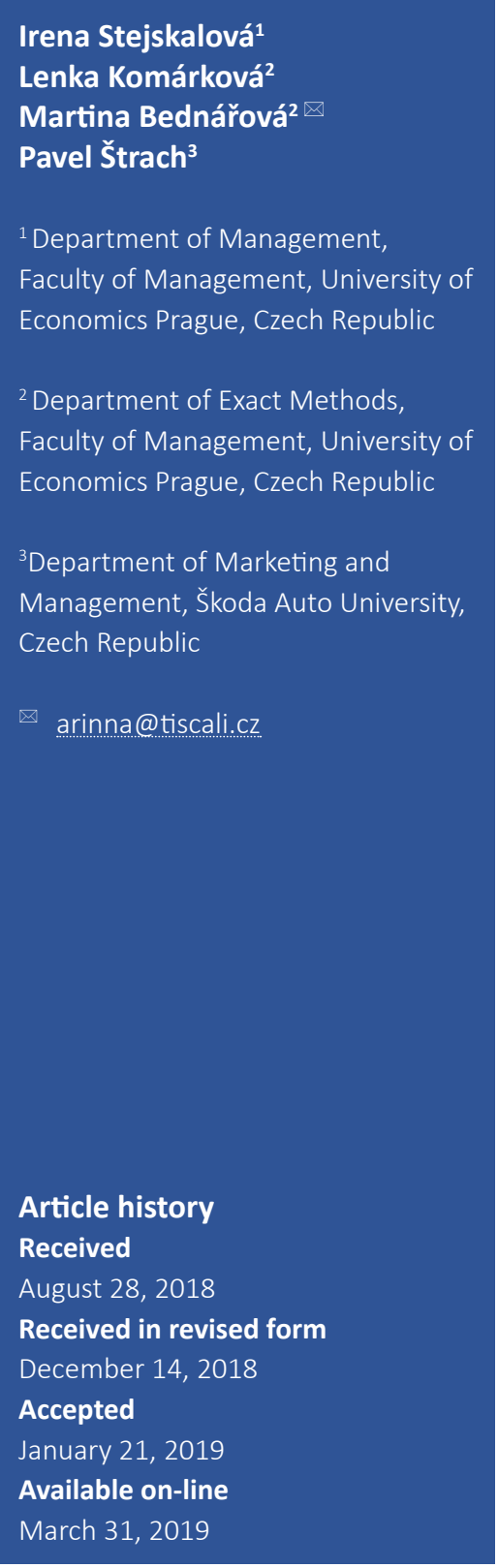

Highlights

- Real-life case studies are considered by students as an appropriate supplement to the accountancy tutorial.

- Men prefer the use of real-life case studies in accounting courses more than women.

- The intervention regarding the inclusion of real-life case studies into tuition has a positive effect on students' acceptance of this non-traditional teaching method.

- Students who have previous experience with traditional accounting education perceive real-life case studies less positively.

\section{INTRODUCTION}

The twenty-first century can be called a century of continuous change. For some, a change may be a challenge and a form of an adrenalin game while for others it may be a source of fear and anxiety (McGrath and Bates, 2013). Assuming that a change is communicated well and participants can listen actively, there is a better chance of its acceptance (Wales, 2002). Changes are also related to education and the teaching methods used. Teaching has been largely founded on using passive forms of teaching, for instance, lectures that are based on the ability to remember facts (Singer and Wiesner, 2013). On the contrary, the core of active teaching is to engage students in the process of teaching (Ciobanu, 2018). The emphasis is placed on the students and the way they use various purposeful teaching activities plus the fact that they are required to think about and analyse what they 
do (Bonwell and Eison, 1991) and understand the heart of a problem (Boyce et al., 2001). An example of these teaching methods is case studies.

The research, conducted by many authors such as Cullen, Richardson and O'Brien (2007), Healy and McCutcheon (2010) and Vondra (2017), implied that case studies can improve soft skills. Accounting has traditionally been a rather conservative discipline (Leventis, Dimitropoulos and Owusu-Ansah, 2013), which includes the utilisation of instruction methods (Bonk and Smith, 1998). With traditional accounting lectures and exercises, students only learn to correctly view the selected business operation in the accounting system. They are not trained to apply their acquired accounting knowledge to managerial decisionmaking in business. However, the problem is that graduates of such traditional university accounting courses should not become accountants, but instead, users of the acquired accounting information who must be able to consider the consequences of their decisions. In order for a graduate to learn to think in context, real-life case studies were introduced into introductory accounting courses.

In this article, we want to build on the conference paper (Stejskalová et al., 2018) that compared the perception of usage of real-life case studies in accounting bachelor courses by Czech and Slovak students in the field of management and we aim to find out which antecedents and factors determine student acceptance of real-life cases in accounting courses. Therefore, and within the theoretical background, attention is focused on the two areas combined in the study: the introduction of nontraditional methods into accounting education and accepting the change in a teaching technique.

\section{THEORETICAL BACKGROUND}

\section{Non-Traditional Methods in Accounting Education}

Changes in the company have put pressure on the key competencies of accountants. Thus, responsible accounting teachers should prepare their students for teamwork, i.e. teach them how to inspire and motivate others to achieve common efficient results (Kermis and Kermis, 2010). Turner and Baskerville (2013) point to a new learning perspective in the work with a lot of information. They recommend that learning abilities development in the first years should be supported by deep learning in the form of individual learning tasks that contribute to the development of the integration of new information into existing knowledge. Furthermore, Goleman $(1996 ; 2011)$ demonstrated that when an educational programme focuses solely on analytical and technical skills, it will have a negative impact on work performance. Educational programmes should also involve the part of the brain that controls feelings and impulses, i.e. emotions.

On the other hand, Buzan (2010) states that current educational systems are designed to actually suppress creative thinking. He notes the drop in creativity from $75 \%$ at primary school to $25 \%$ at university. This is why, within the boundaries of possibilities, it is appropriate to abandon established rules that do not support creative thinking and instead seek alternative solutions. Creative and critical thinking is closely connected with the decision-making process, which plays an important role in managerial work. Accountancy knowledge can be applied very well in the decision-making process (Hall, 2010; Silviu-Virgil, 2014). This is confirmed in the study by Burnett (2003), which furthermore, states that accounting education programmes must continue to innovate the methods used. The combination of school teaching with business practice teaching is the most appreciated in this study. The best form of this outside-the-classroom learning is an internship.

Stahl III and Dunning (2013) point out that accounting education is very often devoted to many separate topics without any attempt to address their integration. McWilliams and Peters (2011) created artificial case studies using financial statements in order to connect accounting and economic knowledge. Similarly, Stahl III and Dunning (2013) propose to foster thinking in the context via Case Studies in Hypo Corporation, where the basic objective is to prepare a set of basic financial statements. Alternative teaching techniques and methodologies for accounting majors include the utilisation of Twitter in introductory courses (Osgerby and Rush, 2015) and more complex simulations for advanced courses such as an audit (Mason Burdon and Munro, 2017).

Weil, McGuigan and Kern (2011) use online forums in the on-going accounting course, where the discussion centres around a case study with the focus on the preparation of the final accounts. Although the specific type and format of such a case study have remained unpublished, it is proposed that the discussions reflect proposals from other available information sources including mass media. The identified benefits of these online discussions were an improvement in students' critical thinking and strengthening of the motivation for a more detailed study of the analysed accounting phenomenon in a wider context. Several other studies focus on using IT technology in accounting education. These include the digital game (Carenys and Moya, 2016) and the educational computer program (Chan et al., 2016) based learning. The Wooten (2016) study compared students' results in classical teaching and teaching supplemented by the use of new methods, namely online courses, out-of-class and open-book exams. As a result, the positive impact of using IT technology for improving student learning has been identified.

Students of traditional introductory accounting courses are confronted with a huge volume of new information that may remain underutilised. This is associated with "information blindness" (Eppler and Mengis, 2004; Sinclair and Ashkanasy, 2005), a phenomenon where human beings are unable to store too much information if it is received in large quantities; therefore, students can easily fall into this trap and only partially use what has been explained to them (Buck, McInnis and Randolph, 2013). "Information blindness" can be prevented, for example, via real-life case studies, where students have to choose explicit or varied options based on the questions asked. This process is sometimes called "creative dysfluency" because students have to make an extraordinary mental effort when making decisions (Alter, 2013; Oppenheimer, 2008).

Stanley and Marsden (2012) have shown that solving real-life 
cases develops the ability to ask questions, to work in teams, and the ability to solve real problems. Therefore, close attention should be paid to the process of introducing alternative teaching methods, not just in accounting. Simon (2007) points out that when teaching accountancy, relatively little attention is devoted to the concept of mapping, i.e. the learning process based on drawings and diagrams. On the other hand, Leauby, Szabat and Maas (2010) could not confirm that students would have achieved better test results if the traditional method of teaching would have been complemented by activity mapping. Moreover, this method requires the acquisition of the necessary mapping software.

Hosal-Akman and Simga-Mugan (2010) analysed the learning success in relation to the teaching method used. As part of the experiment, they split the students into two groups. The first group used traditional teaching methods while the second group applied the new teaching method based on cooperative learning in the form of artificially created case studies. However, the new teaching method did not have any significant effect on the student's results.

The concept of real-life case studies utilised in this paper builds on previous research by Štrach and Stejskalová (2015). Reallife case studies represent slightly edited articles from business newspapers and magazines that address a particular business situation in a company or a specific situation in the industry (An example of a simple real-life case study is presented in the Appendix). The internal motivation of students to study, which is the result of subconscious brain activity, is essential for the development of education and its effectivity (Berková and Krejčová, 2016). Internal motivation activates the right choice decisions. Participants in the decision-making process feel they have things under control. In reality, it is more about the application of will, and the related willingness to participate in the education process (Becker, 1997; Flowerday, Schraw and Stevens, 2004; Reeve, Nix and Hamm, 2003; Dweck 2006). This finding was applied in the accounting course when introducing real-life case studies.

\section{Student Adjustment to Change in Accounting Courses}

In his study, Mladenovic (2000) addressed how to reduce the negative perception of introductory accounting courses because a negative perception is one of the factors that influence students when choosing their profession. He states that the introduction of non-traditional methods of teaching, such as various non-numerical exercises, newspaper articles, or a critical analysis of current issues is not enough to limit the negative perception of accounting courses. On the contrary, the direct intervention of the lecturers in the form of continuous questioning on the course evaluation and the subsequent discussion of this evaluation significantly alleviates the overall negative evaluation of the course by the students. This conclusion was also confirmed by Wessels and Steenkamp (2009) from the South African University.

Similarly, Kanter (2007) and Duhigg (2013; 2016) emphasise the importance of communication in the process of change as the new procedures cannot be simply ordered and instead, the rules that the participants will be willing to accept as a new procedure must be established first. However, Egan (2013) points out that it is necessary to learn how to negotiate and choose different communication strategies for different types of people or interest groups. This can be learned through discussion and reflection. Moreover, according to McGrath and Bates (2013), changes can only be made as fast as the slowest member of the team can adapt.

Adopting a change in accounting education is linked to the fact that some students have become accustomed to acquiring knowledge in previous accounting courses. To change this habit according to Duhigg (2013) means to first realise that our understanding of the approach to teaching is actually a deep-rooted habit. At the same time, students should know that awareness of a habit means taking personal responsibility for its change. However, the problem is that this habit cannot be changed from the outside, i.e. by pressure from the teacher. This can only be done if the student accepts the new teaching method themselves. It is possible to form a new habit by identifying incentives and rewards and then finding alternatives (Duhigg, 2013).

In summary, whereas international researchers concentrate their focus on utilising real-life case studies in teaching and how it impacts on students, this topic is largely unexplored in the context of the Czech Republic. As it has been presented in the study by Machková and Machek (2017), insufficient utilisation of case studies in accountancy education can be identified in the Czech setting. The research results of Košovská, Ferenczi Vaňová and Váryová (2014) also pointed out that passive forms consisting of monologues are used by teachers more than dialogues during instruction, partly due to typical class size and partly due to differentiating classes into lectures and tutorials (seminars). Thus, there exists the potential for the research of real-life case studies in the context.

The aim of our study is to assess the influence of gender and the country on the student adoption of real-life case studies from the conference contribution by Stejskalová et al. (2018) on a larger research sample and, in addition, to consider the influence of other factors related to the change management, namely the previous student experience with traditional accounting education and the introduction of a possible change in teaching.

\section{MATERIALS AND METHODS}

Data were obtained from two faculties of management, one based in the Czech Republic and the other in Slovakia. Namely, the Faculty of Management, the University of Economics in Prague and the Faculty of Economics and Management, the Slovak University of Agriculture in Nitra. Real-life case studies were used at both faculties in the introductory accounting course (within the corresponding extent of two-hour-long lectures and two-hour-long tutorials) for a bachelor's degree and were taught by the same (female) lecturer at both faculties. A traditional onesemester introductory accounting course was supplemented 
by three real-life case studies. These real-life case studies replaced classical tutorials and represented approximately $25 \%$ of the whole teaching time of the tutorials. Students worked on each real-life case study in teams. They discussed and argued their solution process among all team members, i.e. within a group of about 20 students. Finally, the students' result was compared with the teacher's recommended result. If there was any difference, the teacher discussed and justified her proposed result. At the end of the relevant semester (in the Czech Republic it was the winter semester and in Slovakia the summer semester), students were asked to complete a short questionnaire analysing their opinions on the inclusion of real-life case studies into the teaching of the accountancy subject for future managers. As opposed to the study by Stejskalová et al. (2018), more items were examined and our study was extended by including another academic year.

Our data is related to the opinions of students completing two academic years in 2015/16 and 2016/17, whereas in the academic year 2016/17, greater attention was paid to introducing real-life case studies into teaching with the intervention that was intended to ensure students did not refuse case studies a priori, despite not being familiar with these from secondary schools. Intervention at the beginning of real-life case study was done by the teacher, lasted almost one hour and included two main parts. The first part included the explanation of the students' approach to new teaching methods. This means the way how past habits control and do not allow them to accept a new method without reservations. The second part consisted of a detailed explanation of real-life case study meaning and purpose. As LeClair, Thompson and Binks (2018) stated in their study, the process of successful transformation of the learning environment into an active one consists of five steps and the first step is based on articulating the change of teaching. Apart from gender, and also previous interventions and experiences of accountancy education, another factor considered was the country of study, which enabled to conduct a follow-up of the study by Stejskalová et al. (2018).

\begin{tabular}{|c|c|c|c|c|c|c|}
\hline \multirow[b]{2}{*}{ Year } & \multicolumn{2}{|c|}{ Czech Republic (CZ) } & \multicolumn{2}{|c|}{ Slovak Republic (SK) } & \multicolumn{2}{|c|}{ Total } \\
\hline & Male & Female & Male & Female & Male & Female \\
\hline $2015 / 16$ & $26(10)$ & $42(29)$ & $35(26)$ & $102(66)$ & $61(36)$ & $144(95)$ \\
\hline $2016 / 17$ & $24(7)$ & $40(16)$ & $50(25)$ & $144(114)$ & $74(32)$ & $184(130)$ \\
\hline \multirow[t]{2}{*}{ Total } & $50(17)$ & $82(45)$ & $85(51)$ & $246(180)$ & $135(68)$ & $328(225)$ \\
\hline & \multicolumn{2}{|c|}{132 (62) } & \multicolumn{2}{|c|}{$331(231)$} & \multicolumn{2}{|c|}{463 (293) } \\
\hline
\end{tabular}

Table 1: Distribution of respondents given their gender, the country of their faculty and the academic year, 2015-2017 (source: own calculation)

In total, 463 students completed the questionnaire: 205 in the academic year 2015/16 and 258 in the academic year 2016/17. The number of students is summarised in Table 1 according to their gender, the country in which they were studying and the academic year in which accountancy was taught. The number of respondents that studied accountancy at secondary school is shown in brackets. In total, 293 (63.3\%) students had already taken an accounting course during secondary education.

Within the scope of this study, two areas were focused on:

1. The required teaching time dedicated to real-life case studies;

2. The perceived pros and cons of real-life case studies.

The required length of time dedicated specifically to real-life case studies was evaluated by respondents through a ratio scale where the value $\mathrm{p}$ represented the ratio of time given to real-life case studies (aside from typical exercises) within the tutorial stated in per cent (thus the value 100-p demonstrated the percentage ratio of time given to traditional exercises within the tutorial). With regards to the pros and cons of real-life case studies, the respondents selected as many items as they wanted from the following:

- Appropriate tutorial supplement for accountancy;

- Possibility to combine knowledge from more subjects;

- Possibility to partially substitute work experience;

- Fun part of accountancy;
- Wasted time;

- Boring way of teaching;

- Ineffective way of teaching;

- Too difficult to understand.

To analyse the answers in terms of the selected factors, linear or logistic regression was used that was conducted in the statistical software R (R Core Team, 2018). The statistical evidence was assessed at the 5\% significance level.

\section{RESULTS}

\section{Required teaching time dedicated to real-life case studies}

First, descriptive statistics were carried out. According to the average answer of the respondents included in the study, it followed that a third of tutorial time should be dedicated to case studies and the remaining two thirds to exercises. This ratio seems considerably different when focusing on particular groups of respondents, see Table 2. It is apparent that the Slovak respondents accepted real-life case studies better than the Czech respondents and, furthermore, men better than women. Higher average values were achieved in the academic year $2016 / 17$ than in $2015 / 16$, that is, real-life case studies were accepted better in the second observed term 
where a slight intervention occurred. Educational experience with accountancy at secondary school lowered the values of achieved averages in most cases, that is, respondents who were familiar with accountancy taught in the way of exercises at secondary school wanted less time given to real-life case studies on average. The most favourable ratio - 44:56 - for real-life case studies was achieved by the men at the Slovak faculty with an accountancy tutorial in the academic year $2016 / 17$. On the contrary, the least favourable result (one- sixth of teaching time) was for the women at the Czech faculty in the academic year 2015/16 with the previous educational experience of accountancy at secondary school.

Multiple linear regression was subsequently carried out, whereas all four factors entered the linear model via 0-1 dummy variables (Experience: $0-$ No, 1 - Yes, Gender: $0-$ Male, 1 - Female, Country: 0 - CZ, 1 - SK, Year: 0 - 15/16, 1 - 16/17). Observed differences arising from descriptive statistics proved to be statistically significant even after

\begin{tabular}{|c|c|c|c|c|c|c|}
\hline \multirow[b]{2}{*}{ Year } & \multicolumn{2}{|c|}{ Czech Republic (CZ) } & \multicolumn{2}{|c|}{ Slovak Republic (SK) } & \multicolumn{2}{|c|}{ Total } \\
\hline & Male & Female & Male & Female & Male & Female \\
\hline $2015 / 16$ & $24.8(18.0)$ & $20.0(16.6)$ & $42.1(43.8)$ & $32.7(31.8)$ & $34.7(36.7)$ & $29.0(27.2)$ \\
\hline $2016 / 17$ & $32.6(37.1)$ & $28.0(28.1)$ & $43.8(39.2)$ & $36.0(33.5)$ & $40.2(38.8)$ & $34.2(32.8)$ \\
\hline Total & $28.5(25.9)$ & $23.9(20.7)$ & $43.1(41.6)$ & 34.6 (32.9) & $37.7(37.6)$ & $31.9(30.4)$ \\
\hline & 25.7 & & 36.8 & & 33.6 & \\
\hline
\end{tabular}

Table 2: Mean responses given the respondents' characteristics as the gender, country and academic year. In brackets are the means listed separately for respondents with previous experience of accounting lessons from a secondary school, 2015-2017 (source: own calculation)

\begin{tabular}{ccc|c|cr} 
Rank by Effect Size & Factor & Difference & Estimate for Diff. & $\begin{array}{c}95 \% \text { Conf. Int. for } \\
\text { Diff. }\end{array}$ & $p$-value \\
\hline 1 & Country & SK vs CZ & 12.75 & $(9.63,15.87)$ & $<0.001$ \\
\hline 2 & Gender & Female vs Male & -6.32 & $(-9.38,-3.26)$ & $<0.001$ \\
\hline 3 & Experience & Yes vs No & -5.61 & $(-8.55,-2.68)$ & $<0.001$ \\
\hline 4 & Year & $16 / 17$ vs 15/16 & 4.19 & $(1.43,6.95)$ & 0.003 \\
\hline
\end{tabular}

Table 3: Linear regression results in the form of estimates for the difference in means and the related $95 \%$ confidence intervals and p-values, 2015-2017 (source: own calculation)

adjusting the impact of other observed factors (condition ceteris paribus), see the results of the regression analysis represented in Table 3 where the $p$-value is significantly lower than $5 \%$ for all four factors. The greatest difference in the perception of real-life case studies was ceteris paribus between the countries of study. Slovaks studying a management degree preferred more time for case studies, precisely by 12.75 percentage points more on average than their Czech colleagues with the same tracked characteristics. From the observed factors, the intervention used in the academic year 2016/17 had the least impact on the result but is still statistically significant.

\section{Perceived pros and cons of real-life case studies}

The respondents selected mostly positive items in their answers rather than negative ones. The majority $(74.7 \%)$ of respondents considered the real-life case-based studies as an appropriate supplement to the accountancy tutorial in particular. About $40 \%$ of respondents were in favour of partially replacing practical experience with them. The third most common answer was that real-life case studies combine knowledge gained from other subjects (39.1\%). It can be seen in Table 4 that respondents who have had experience with accountancy education at secondary school perceived real-life case studies in a more critical light than those who have not had a similar experience, even though they viewed them as a fun part of learning.

The impact of intervention in the academic year 2016/2017 was confirmed as expected through the respondents' answers. Positive items were selected more frequently compared to the last academic year and negative items were selected less frequently.

Table 5 represents the results from eight models of multiple logistic regression corresponding to eight items in the questionnaire (arranged according to how frequently they were selected) where the response is formed by the $0-1$ quantity characterising the selection of a particular item $(0-$ not selected, 1 - selected). When focusing on the pros of reallife case studies (items 1 to 4 in Table 5), it is apparent that the tendency direction is diversified in the Country column. According to point estimates for odds ratios (ORs), it is more likely that items 1 and 4 are selected by the Slovaks (estimate for $\mathrm{OR}>1$ ) and, moreover, it is more likely that items 2 and 3 are selected by the Czechs (estimate for OR $<1$ ). However, these tendencies are not statistically significant $(p>0.05)$. The Experience factor impacts the perception of case studies as anticipated, apart from item 4 "Fun Part of Learning" where the probability of selecting this positive item is higher amongst 


\begin{tabular}{|c|c|c|c|c|c|c|c|c|c|}
\hline \multirow[b]{2}{*}{ Year } & \multicolumn{2}{|c|}{ Country } & \multicolumn{2}{|c|}{ Gender } & \multicolumn{2}{|c|}{ Experience } & \multicolumn{2}{|c|}{ Year } & \multirow{2}{*}{ Total } \\
\hline & CZ & SK & $\mathbf{M}$ & $\mathbf{F}$ & $\mathbf{N}$ & $\mathbf{Y}$ & $15 / 16$ & $16 / 17$ & \\
\hline $\begin{array}{l}\text { + Appropriat Teaching } \\
\text { Supplement }\end{array}$ & 74.2 & 74.9 & 77.0 & 73.8 & 79.4 & 72.0 & 70.7 & 77.9 & 74.7 \\
\hline $\begin{array}{l}\text { + Partial Compensation } \\
\text { for Real Experience }\end{array}$ & 41.7 & 39.6 & 44.4 & 38.4 & 43.5 & 38.2 & 36.6 & 43.0 & 40.2 \\
\hline $\begin{array}{l}\text { + Combining Knowledge from } \\
\text { More Subjects }\end{array}$ & 43.9 & 37.2 & 37.8 & 39.6 & 42.4 & 37.2 & 28.3 & 47.7 & 39.1 \\
\hline + Fun Part of Learning & 13.6 & 16.9 & 12.6 & 17.4 & 11.8 & 18.4 & 14.6 & 17.1 & 16.0 \\
\hline - Too Difficult to Understand & 13.6 & 2.4 & 3.7 & 6.4 & 4.7 & 6.1 & 10.7 & 1.6 & 5.6 \\
\hline - Boring Way of Study & 5.3 & 5.1 & 2.2 & 6.4 & 1.8 & 7.2 & 6.8 & 3.9 & 5.2 \\
\hline - Useless Waste of Time & 7.6 & 3.9 & 4.4 & 5.2 & 2.4 & 6.5 & 6.8 & 3.5 & 5.0 \\
\hline - Ineffective Way of Teaching & 5.3 & 3.6 & 2.2 & 4.9 & 2.4 & 5.1 & 5.9 & 2.7 & 4.1 \\
\hline
\end{tabular}

Table 4: Percentages of responses given the respondents characteristics as the gender, country and academic year, 2015-2017 (source: own calculation)

students with previous educational experience of accountancy at secondary school.

The effect of the Gender factor on the perception of case studies has not been statistically confirmed; nevertheless, women tended to perceive real-life case studies as "Combining Knowledge from More Subjects" or "Fun Part of Learning" more frequently (ceteris paribus) than men. Intervention impacts positive items as anticipated. In the academic year $2016 / 17$, the pros of real-life case studies were selected more frequently. In particular, for item 3 "Combining Knowledge from More Subjects", the difference in rating among the years is statistically significant.

\begin{tabular}{|c|c|c|c|c|c|}
\hline No. & Item & Country SK vs CZ & Gender Female vs Male & Experience Yes vs No & Year $16 / 17$ vs $15 / 16$ \\
\hline 1 & $\begin{array}{l}\text { + Appropriate Teaching } \\
\text { Supplement }\end{array}$ & $\begin{array}{c}1.10(0.68,1.79) \\
p=0.685\end{array}$ & $\begin{array}{c}0.88(0.54,1.43) \\
p=0.607\end{array}$ & $\begin{array}{c}0.67(0.42,1.07) \\
p=0.090\end{array}$ & $\begin{array}{c}1.45(0.95,2.21) \\
p=0.088\end{array}$ \\
\hline 2 & $\begin{array}{l}+ \text { Partial Compensation for } \\
\text { Real Experience }\end{array}$ & $\begin{array}{c}0.95(0.62,1.46) \\
p=0.824\end{array}$ & $\begin{array}{c}0.81(0.53,1.22) \\
p=0.307\end{array}$ & $\begin{array}{c}0.84(0.56,1.26) \\
p=0.398\end{array}$ & $\begin{array}{c}1.32(0.90,1.92) \\
p=0.155\end{array}$ \\
\hline 3 & $\begin{array}{l}\text { + Combining Knowledge from } \\
\text { More Subjects }\end{array}$ & $\begin{array}{c}0.69(0.45,1.07) \\
p=0.101\end{array}$ & $\begin{array}{c}1.16(0.75,1.79) \\
p=0.503\end{array}$ & $\begin{array}{c}0.85(0.56,1.28) \\
p=0.433\end{array}$ & $\begin{array}{c}2.39(1.61,3.55) \\
p<0.001\end{array}$ \\
\hline 4 & + Fun Part of Learning & $\begin{array}{c}1.11(0.61,2.01) \\
p=0.737\end{array}$ & $\begin{array}{c}1.33(0.73,2.40) \\
p=0.350\end{array}$ & $\begin{array}{c}1.59(0.90,2.82) \\
p=0.110\end{array}$ & $\begin{array}{c}1.19(0.71,1.98) \\
p=0.509\end{array}$ \\
\hline 5 & - Too Difficult to Understand & $\begin{array}{c}0.15(0.06,0.36) \\
p<0.001\end{array}$ & $\begin{array}{c}2.34(0.81,6.75) \\
p=0.117\end{array}$ & $\begin{array}{c}1.54(0.61,3.88) \\
p=0.357\end{array}$ & $\begin{array}{c}0.15(0.05,0.45) \\
\quad p<0.001\end{array}$ \\
\hline 6 & - Boring Way of Study & $\begin{array}{c}0.78(0.30,1.99) \\
p=0.596\end{array}$ & $\begin{array}{c}2.65(0.77,9.18) \\
p=0.123\end{array}$ & $\begin{array}{c}4.03(1.16,13.94) \\
p=0.028\end{array}$ & $\begin{array}{c}0.55(0.23,1.29) \\
\quad p=0.167\end{array}$ \\
\hline 7 & - Useless Waste of Time & $\begin{array}{c}0.42(0.17,1.03) \\
p=0.058\end{array}$ & $\begin{array}{c}1.10(0.41,2.93) \\
p=0.848\end{array}$ & $\begin{array}{c}3.36(1.09,10.40) \\
p=0.035\end{array}$ & $\begin{array}{c}0.56(0.23,1.33) \\
p=0.188\end{array}$ \\
\hline 8 & - Ineffective Way of Teaching & $\begin{array}{c}0.59(0.22,1.59) \\
p=0.298\end{array}$ & $\begin{array}{c}2.18(0.61,7.76) \\
p=0.227\end{array}$ & $\begin{array}{c}2.22(0.71,6.97) \\
p=0.171\end{array}$ & $\begin{array}{c}0.47(0.18,1.23) \\
p=0.123\end{array}$ \\
\hline
\end{tabular}

Table 5: Logistic regression results in the form of estimates for odds ratios and the related Wald's $95 \%$ confidence intervals and $p$-values, 2015-2017 (source: own calculation)

In terms of cons related to case studies (items 5 to 8 ), four statistically significant results were identified. The negative item "Too Difficult to Understand" was influenced by the Country and Year factors. The Czechs were more likely to select this item than the Slovaks with the same characteristics, or as the case may be, in the academic year $2015 / 16$ as opposed to the following year for students of the same type. In other words, intervention seemed to help to reduce the negative perception of real-life case studies as difficult to understand the form of tutorial. With regards to a previous educational experience of accountancy, this experience 
seemed to mainly impact the higher probability of perceiving reallife case studies as a boring tutorial or a waste of time.

\section{DISCUSSION}

The effectiveness of methodologies and methods in the process of knowledge acquisition depends on the circumstances and the environment in which they are formed (Lopes, 2015). This is consistent with the results of our research that the adoption of real-life case studies is related to the previous experience of the traditional ways of accounting education. Teachers must be able to pass the information onto students who previously attended accounting classes as well as to students who are complete beginners. In terms of students with previous experience, this concerns breaking the barrier associated with previous habits (and possibly changing previous attitudes towards the subject) and in terms of students without previous experience, it is easier to implement new teaching practices or to arouse their interest in the given subject. Our study shows how teacher communication with students can change the perception of new teaching practices in accounting. This result is consistent with the conclusions of Mladenovic (2000) or Wessels and Steenkamp (2009). On the other hand, if we consider students' previous work experience, Ballantine and Larres (2004) stress that these students do not perceive the benefits of using case studies in accounting any differently than those students who have not yet had experience of accounting.

A good teacher should definitely aim to help students to become wiser. According to Goldberg (2006), wisdom is usually observed in people who are able to almost instantly, and seemingly with little effort, resolve a difficult or unexpected problem. This ability is not defined solely by a large number of "pattern" situations, phenomena or behaviours, i.e. by a large number of facts stored in the left hemisphere of the brain. The traditional accounting education method contributes to managers' wisdom to a much lesser degree than education based on real-life case studies. The ability to solve problems better after the introduction of the case studies into accounting education is also confirmed by Stanley and Marsden (2012). A teaching method itself is one of the key components of teaching quality and delivery of learning outcomes (Bidabadi et al., 2016; Leeman and Wardekker, 2011; O'Neill, 2012), which can be assessed by reflecting on feedback from learners. It can be said that the use of real-life case studies in accountancy education is not only innovative but also contributes to education quality. As stated by Vnoučková, Urbancová and Smolová (2017), the current university environment is highly competitive and to ensure quality is paramount.

There is a number of other studies that explore the possible determinants of study success in accounting courses. Doran, Bouillon and Smith (1991) investigated the dependency of study results in the introductory and ongoing accounting course using gender, previous study results, and if they had experienced accountancy classes in their secondary school. While the previous study results turned out to be decisive, the study of accountancy at secondary school, the gender of the student and the teacher had no statistically significant effect on learning success. In our case, we did not focus on the subject's study results but investigated the acceptance of case studies with respect to similar determinants. However, in our study, student gender and their previous experience with accounting courses during secondary education had a statistically significant influence.

In addition, this study confirmed that the approach of learners to accounting has been influenced by previous experience with the discipline, hence in line with deep-rooted habits as suggested by Duhigg (2013). In our study, previous experience with accounting had a significant effect on adoption of real-life case studies. Students with previous exposure to accounting classes expressed a less positive view on the introduction of novel teaching method.

The real-life case studies, however, have undoubtedly expanded students' thinking and according to our study, students considered them beneficial. Therefore, we came to similar conclusions as Stanley and Marsden (2012). Berényi and Deutsch (2018), who have conducted research about the most useful teaching methods state that business students prefer active participation in teaching and simulations and that case studies were evaluated better than lectures. On the other hand, if we take into account the subject being taught, here accounting, lectures have been identified by students as a suitable teaching method.

However, our study is limited as it is based on the results of a questionnaire survey from two academic years at two universities. Moreover, the questionnaire, although containing semi-open questions, was the only data acquisition method used. In addition, the adoption of new practices in accounting education is explored in this article only from the students' point of view. Future studies could consider the impact of real-life case studies on the acquisition of learning outcomes, the satisfaction of instructors or classroom dynamics. Other contingent factors and antecedents such as previous practical experience with accounting (in line with Ballantine and Larres, 2004), overall student results (in accordance to Hosal-Akman and Simga-Mugan, 2010) or retention (as suggested by Sargent, Borthick and Lederberg, 2011) could be considered as well.

\section{CONCLUSION}

Our study suggests a number of particular results related to the inclusion of real-life case studies into accountancy teaching and its acceptance by students. It is evident that the introduction of novel teaching methods such as the real-life case studies shall be performed with caution in the discipline of accounting and that there might be several factors to consider. Firstly, men seem to prefer the use of case studies in teaching and perceive them positively. This could be linked to them being more open to and accepting of changes in a better way. Secondly, the significance of previous intervention regarding the inclusion of real-life case studies into tuition by tutors has been confirmed. If students are informed, and the concept of the new teaching method is explained, this reflects in a more positive perception of the case studies. It is important to emphasise that students should be well informed. Consequently, students understand what is to be expected so can, therefore, prepare themselves for the situation of the new way of teaching. In addition, our 
study examined the differences between students who have previously experienced an accountancy tutorial at secondary school and those who have not. The results have clearly indicated that students with previous accountancy tutorial experience perceive real-life case studies less positively than their colleagues. A possible explanation for this could be a combination of a whole range of aspects. Students are already familiar with a certain way of teaching and are not inclined towards a change in teaching. They might automatically view a barrier in the new way of teaching that could not be easily overcome. Another factor could be the tutor's personality and the students' personal traits. Furthermore, students with previous experience with accounting may need a different intervention/explanation for an instructor than other students. We plan to extend the study with a follow-up research paper, which will cover two main areas. Having identified the importance of using interventions at the beginning of the learning process, we intend to focus on different types of interventions and their impact on the adoption of case studies by students. Furthermore, we aim to investigate changes in students' abilities before and after using real-life case studies in the accounting course.

\section{ACKNOWLEDGEMENTS}

This paper was supported by the Czech Science Foundation (GAČR) under the grant, number 18-01159S.

\section{REFERENCES}

Alter, A.L. (2013) 'The benefits of cognitive disfluency', Current Directions in Psychological Science, vol. 22, no. 6, pp. 437-442. https://doi.org/10.1177/0963721413498894

Ballantine, J.A. and Larres, P.M. (2004) 'A critical analysis of students' perceptions of the usefulness of the case study method in an advanced management accounting module: the impact of relevant work experience', Accounting Education, vol. 13, no. 2, pp. 171-189. https://doi.org/10.1080/09639280410001676885

Becker, D.A.A. (1997) 'The effects of choice on auditors' intrinsic motivation and performance', Behavioral Research in Accounting, vol. 9, pp. 1-19.

Berényi, L. and Deutsch, N. (2018) 'Effective teaching methods in business higher education: a students' perspective', International Journal of Education and Information Technologies, vol. 12, pp. $37-45$.

Berková, K. and Krejčová, K. (2016) 'Effect of teachers' abilities on students' motivation with varying levels of intellectual abilities in the economics', Journal on Efficiency and Responsibility in Education and Science, vol. 9, no. 3, pp. 81-87. https://doi. org/10.7160/eriesj.2016.090304

Bidabadi, N.S., Isfahani, A.N., Rouhollahi, A. and Khalili, R. (2016) 'Effective teaching methods in higher education: requirements and barriers', Journal of advances in medical education \& professionalism, vol. 4, no. 4, pp. 170-178.

Bonk, C.J. and Smith, G.S. (1998) 'Alternative instructional strategies for creative and critical thinking in the accounting curriculum', Journal of Accounting Education, vol. 16, no. 2, pp. 261-293.

Bonwell, C.C. and Eison, J.A. (1991) Active Learning: Creating Excitement in the Classroom, 1991 ASHE-ERIC Higher Education Reports, ERIC Clearinghouse on Higher Education, The George Washington University, Washington, DC.

Boyce, G., Williams, S., Kelly, A. and Yee, H. (2001) 'Fostering deep and elaborative learning and generic (soft) skill development: the strategic use of case studies in accounting education', Accounting Education: An International Journal, vol. 10, no. 1, pp. 37-60. https://doi.org/10.1080/09639280121889

Buck, J.L., McInnis, E. and Randolph, C. (2013) 'The new frontier of education: The impact of smartphone technology in the classroom', American Society for Engineering Education, vol. 1, no. 1, pp. 1-11.

Burnett, S. (2003) 'The future of accounting education: A regional perspective', Journal of Education for Business, vol. 78, no. 3, pp. 129-134. https://doi.org/10.1080/08832320309599709

Buzan, T. (2010) Use your head: How to unleash the power of your mind. Pearson, BBC Active, Harlow, England.

Carenys, J., Moya, S. (2016) 'Digital game-based learning in accounting and business education', Accounting Education, vol. 25, no. 6, pp. 598-651. https://doi.org/10.1080/09639284.2016. 1241951

Chan, S.H., Song, Q., Rivera, L.H., Trongmateerut, P. (2016) 'Using an educational computer program to enhance student performance in financial accounting', Journal of Accounting Education, vol. 36, pp. 43-64. https://doi.org/10.1016/j.jaccedu.2016.05.001

Ciobanu, N.R. (2018) 'Active and Participatory Teaching Methods', European Journal of Education, vol. 1, no. 2, pp. 69-72. https:// dx.doi.org/10.26417/ejed.v1i2.p69-72

Cullen, J., Richardson S. and O'Brien, R. (2007) 'Exploring the teaching potential of empirically-based case studies', Accounting Education, vol. 13, no. 2, pp. 251-266. https://doi.org/10.1080/0 9639280420001676648

Doran, B.M., Bouillon, M.L. and Smith, C.G. (1991) 'Determinants of Student Performance in Accounting Principles I and II', Issues in Accounting Education, vol. 6, no. 1, pp. 74-84.

Duhigg, C. (2013) The Power of Habit: Why We Do What We Do, and How to Change, Random House, London, United Kingdom.

Duhigg, C. (2016) Smarter Faster Better: The Secrets of Being Productive, Random House, New York.

Dweck, C.S. (2006) Mindset: The New Psychology of Success. Random House Books, New York, USA.

Egan, G. (2013) The skilled helper: A problem-management and opportunity-development approach to helping, Cengage Learning, Belmont, USA.

Eppler, M. and Mengis, J. (2004) 'The Concept of Information Overload: A Review of Literature from Organization Science, Accounting, Marketing, MIS, and Related Disciplines', The Information Society, vol. 20, no. 5, pp. 325-344. https://doi. org/10.1080/01972240490507974

Flowerday, T., Schraw, G. and Stevens, J. (2004) 'The role of choice and interest in reader engagement', The Journal of Experimental Education, vol. 72, no. 2, pp. 93-114. https://doi.org/10.3200/ JEXE.72.2.93-114 
Goldberg, E. (2006) The wisdom paradox: How your mind can grow stronger as your brain grows older, Penguin, New York, USA.

Goleman, D. (1996) 'Emotional Intelligence. Why It Can Matter More than IQ', Learning, vol. 24, no. 6, pp. 49-50.

Goleman, D. (2011) What Makes a Leader?, Harvard Business School Publishing, Boston, USA.

Hall, M. (2010) 'Accounting information and managerial work', Accounting, Organizations and Society, vol. 35, no. 3, pp. 301315. https://doi.org/10.1016/j.aos.2009.09.003

Healy, M. and McCutcheon, M. (2010) 'Teaching with Case Studies: An Empirical Investigation of Accounting Lecturers' Experiences', Accounting Education, vol. 19, no. 6, pp. 555-567. https://doi.org/10.1080/09639284.2010.501577

Hosal-Akman, N. and Simga-Mugan, C. (2010) 'An assessment of the effects of teaching methods on the academic performance of students in accounting courses', Innovations in Education and Teaching International, vol. 47, no. 3, pp. 251-260. https://doi.or g/10.1080/14703297.2010.498176

Kanter, R.M. (2007) 'The enduring skills of change leaders', NHRD Journal, vol. 1, pp. 53-59. https://doi.org/10.1002/ 1t1.40619991305

Kermis, G. and Kermis, M. (2010) 'Professional Presence and Soft Skills: A Role for Accounting Education', Journal of Instructional Pedagogies, vol. 2, pp. 1-10.

Košovská, I., Ferenczi Vaňová, A. and Váryová, I. (2014) 'Tvorivost' učitel'a ako predpoklad skvalitňovania vzdelávacieho procesu', Dnešné trendy inovácií, pp. 88-95.

Leauby, B.A., Szabat, K.A. and Maas, J.D. (2010) 'Concept Mappingan Empirical Study in Introductory Financial Accounting 1', Accounting Education: An International Journal, vol. 19, no. 3, pp. 279-300. https://doi.org/10.1080/09639280903412334

LeClair, R.J., Thompson, K.H. and Binks, A.P. (2018) 'A Universal Guide to Transitioning Didactic Delivery into an Active Classroom', Medical Science Educator, pp. 1-8. https://doi. org/10.1007/s40670-018-0599-1

Leeman, Y. and Wardekker, W. (2011) 'Redesigning vocational education: The possibilities of design-based research' Journal of Curriculum Studies, vol. 43, no. 3, pp. 313-331. https://doi.org/1 $0.1080 / 00220272.2011 .557838$

Leventis, S., Dimitropoulos, P. and Owusu-Ansah, S. (2013) 'Corporate governance and accounting conservatism: Evidence from the banking industry' Corporate Governance: $A n$ International Review, vol. 21, no. 3, pp. 264-286. https://doi. org/10.1111/corg. 12015

Lopes, I.T. (2015) 'Research methods and methodology towards knowledge creation in accounting', Contaduría y Administración, vol. 60, pp. 9-30. https://doi.org/10.1016/j.cya.2015.08.006

Machková, E. and Machek, O. (2017) 'Using Case Studies in Accounting Education at the Czech Universities', PaidagogosJournal of Education in Contexts, vol. 16, no. 2, pp. 107-124.

Mason Burdon, W. and Munro, K. (2017) 'Simulation-is it all worth it? The impact of simulation from the perspective of accounting students', The International Journal of Management Education, vol. 15, no. 3, pp. 429-448. https://doi.org/10.1016/j. ijme.2017.07.001

McGrath, J. and Bates, B. (2013) The Little Book of Big Management Theories:... and how to use them, Pearson, London, United Kingdom.

McWilliams, V.B. and Peters, M.F. (2011) 'An integrated approach to beginning financial accounting and finance courses', Issues in
Accounting Education, vol. 27, no. 1, pp. 299-336. https://doi. org/10.2308/iace-50090

Mladenovic, R. (2000) 'An investigation into ways of challenging introductory accounting students" negative perceptions of accounting', Accounting Education, vol. 9, no. 2, pp. 135-155. https://doi.org/10.1080/09639280010000147

O‘Neill, D.K. (2012) 'Designs that fly: What the history of aeronautics tells us about the future of design-based research in education', International Journal of Research \& Method in Education, vol. 35, no. 2, pp. 119-140. https://doi.org./10.1080/174372 7X.2012.683573

Oppenheimer, D.M. (2008) 'The secret life of fluency', Trends in cognitive sciences, vol. 12 , no. 6, pp. 237-241. https://doi. org/10.1016/j.tics.2008.02.014

Osgerby, J. and Rush, D. (2015) ‘An exploratory case study examining undergraduate accounting students" perceptions of using Twitter as a learning support tool', The International Journal of Management Education, vol. 13, no. 3, pp. 337-348. https://doi. org/10.1016/j.ijme.2015.10.002

$\mathrm{R}$ Core Team (2018) 'R: A language and environment for statistical computing', R Foundation for Statistical Computing, Vienna, Austria, available at: http://www.R-project.org/

Reeve, J., Nix, G. and Hamm, D. (2003) 'Testing models of the experience of self-determination in intrinsic motivation and the conundrum of choice', Journal of educational psychology, vol. 95, no. 2, pp. 375-392. https://doi.org/10.1037/00220663.95.2.375

Sargent, C.S., Borthick, A.F. and Lederberg, A.R. (2011) 'Improving retention for principles of accounting students: Ultra-short online tutorials for motivating effort and improving performance', Issues in Accounting Education, vol. 26, no. 4, pp. 657-679.

Silviu-Virgil, C. (2014) 'The importance of the accounting information for the decisional process', Annals Of The University Of Oradea, Economic Science Series, vol. 23, no. 1, pp. 593-603.

Simon, J. (2007) 'Concept mapping in a financial accounting theory course', Accounting Education, vol. 16, no. 3, pp. 273-308. https://doi.org/10.1080/09639280701430306

Sinclair, M. and Ashkanasy, N.M. (2005) 'Intuition myth or a decision-making tool?', Management Learning, vol. 36, no. 3, pp. 353-370. https://doi.org/10.1177/1350507605055351

Singer, R.A. and Wiesner, T. (2013) 'The Future of Undergraduate Accounting Programs and Curricula', Management Accounting Quarterly, vol. 14, no. 4, pp. 22-31.

Stanley, T. and Marsden, S. (2012) 'Problem-based learning: Does accounting education need it?', Journal of Accounting Education, vol. 30, no. 3-4, pp. 267-289. https://dx.doi.org/10.1016/j. jaccedu.2012.08.005

Stahl III, C.E. and Dunning, G.R. (2013) 'Instructional Case-Hypo Corporation, The Financial Accounting Educative Process, A Void!' Journal of Accounting and Finance, vol. 13, no. 6, pp. 209-221.

Stejskalová, I., Bednářová, M., Komárková, L. and BartošováVrbová, M. (2018) 'Case Studies in Accounting Courses for Managers: Czech and Slovak Comparison' In: Proceedings of the 15th International Conference Efficiency and Responsibility in Education 2018 (ERIE 2018) Prague: Czech University of Life Sciences Prague, 2018, pp. 373-379.

Štrach, P. and Stejskalová, I. (2015) 'New Didactic Approaches in Accounting: Moving Beyond the Calculation Exercise', In Proceedings of Business and Management Conferences 
(No. 2304424), International Institute of Social and Economic Sciences.

Turner, M., Baskerville, R. (2013) 'The experience of deep learning by accounting students', Accounting Education: An International Journal, vol. 22, no. 6, pp. 582-604. https://doi.org/10.1080/096 39284.2013.847323

Vnoučková, L., Urbancová, H. and Smolová, H. (2017) 'Factors Describing Students' Perception on Education Quality Standards', Journal on Efficiency and Responsibility in Education and Science, vol. 10, no. 4, pp. 109-115. https://doi.org/10.7160/ eriesj.2017.100403

Vondra, Z. (2017) 'Quality Control and Improvements Mechanism of Study Field - Focused on Professional Study Field', Journal on Efficiency and Responsibility in Education and Science, vol. 10, no. 1, pp. 16-23. https://dx.doi.org/10.7160/eriesj.2017.100103
Wales, S. (2002). Why coaching? Journal of change management, vol. 3, no. 3, pp. 275-282. https://doi.org/10.1080/714042542

Weil, S., McGuigan, N. and Kern, T. (2011) 'The usage of an online discussion forum for the facilitation of case-based learning in an intermediate accounting course: A New Zealand case', Open Learning, vol. 26, no. 3, pp. 237-251. https://doi.org/10.1080/02 680513.2011.611685

Wessels, P.L. and Steenkamp, L.P. (2009) 'An investigation into students' perceptions of accountants', Meditari: Research Journal of the School of Accounting Sciences, vol. 17, no. 1, pp. 117-132.

Wooten, T. (2016) 'Leveraging online testing to enhance student learning', Advances in Accounting Education, vol. 19, pp. 141163. https://doi.org/10.1108/S1085-462220160000019006

APPENDIX - An Example of a Real-Life Case Study

\section{BASIC ACCOUNTING CATEGORIES}

\section{Objective:}

If a student is able to answer the questions asked, and solve the underlying calculations in order to support their own decisionmaking process following a real-life case study, then they will be able to verify for themselves the understanding of the context between the selected basic accounting categories and will be able to place them on the balance sheet. At the same time, they are able to learn how the value of certain accounting categories affects managerial decisions. The case study is based on the article of the same name by Iva Špačková, ČTK.

\section{Source:}

http://ekonomika.idnes.cz/hospodareni-ceske-pojistovny-dkeekoakcie.aspx?c=A120323_171207_ekoakcie_spi

\section{Assignment:}

\section{Česká pojišt'ovna saw their profit fall last year by two-thirds to 3.5 billion CZK}

(truncated text)

Česká pojištovna is part of Generali PPF Holding B.V., which operates in fourteen Central and Eastern European countries. Generali PPF Holding manages assets of 15 billion EUR (over 375 billion CZK) through subsidiaries and provides their services to more than 13 million clients in the region. The holding headquarters is based in the Netherlands and its main branch office is based in Prague. It is a joint venture of Assicurazioni Generali with a 51\% stake and the PPF Group, which owns a $49 \%$ stake in the holding.

Česká pojišt'ovna earned two-thirds less in 2011 than in 2010 when profits fell to 3.55 billion CZK. The largest insurer on the Czech market collected insurance premiums of 33.4 billion $\mathrm{CZK}$, which was one-tenth less than the previous year.

The equity of Česká pojištovna at the end of 2011 amounted to 17.5 billion CZK and the balance sheet total was 116.5 billion
CZK. The total gross technical provisions amounted to 86.3 billion CZK.

"Last year we started to fundamentally change Česká pojišt'ovna. Starting with the introduction of procedural changes to strengthen the performance and dynamics of the business network, we introduced a number of new products and services and began to change the culture within the company. Our share of newly concluded policies has grown once again," says Pavel Řehák, the CEO of Česká pojištovna commenting on last year's results.

In his opinion, the changes had a positive impact on operating profit, which has increased year-on-year by 548 billion CZK. One-off operations were a contributing factor to the huge gain. The year-on-year loss on insurance premiums was predominately due to the continuing decline in the car insurance market and a smaller volume of life insurance products", added Řehák.

\section{Tasks to Solve:}

1. After reading the article, how would you assess Česká pojištovna? Is it a successful, trustworthy company, does it have financial problems that it is unable to deal with ...?

2. Select the basic accounting categories from the first three paragraphs of the text and place them in the prepared balance sheet table. Assess the relationship between the balance sheet total and equity; also the relationship between the balance sheet sum and the technical provisions.

3. What does the company have to do in order to prevent a decline in profit?

4. Explain: "One-off operations were the contributing factor to the huge gain"?

5. What is the difference between the accounting categories for "technical reserves" and the "reserve fund"?

6. How did your opinion change in terms of the financial situation of Česká pojišt'ovna after solving the abovementioned tasks? 
Balance Sheet: 